\title{
Analisis Potensi Kesiapan Petani Padi Sawah untuk Bisa Menerima Rencana Program Pengembangan Usaha Sutera Kerakyatan di Kawasan Irigasi Teknis Kecamatan Belitang
}

Iman sulaiman, Maryadi, Mirza Antoni

\begin{abstract}
The purposes of this research were to : (1) Measure the potential yard, free time, farmer's income and potential of readiness farmers in establishing PUSK programme at the area technical irrigation channels, (2) Analyze opportunity of farmer's decision to be clasified in accordance with social economic potenttially in PUSK programme. The research was conducted in Belitang Sub District OKU Timur Regency. This research was done on April until August 2015 by survey and disproporsionated stratified random sampling method, and also took 63 samples. The research found that farmers have a yard $>200 \mathrm{~m}^{2}$ were $93,65 \%$ and the free time of work were $169.045 \mathrm{HOK} / \mathrm{year}$. While, the average farmer's income were Rp.19.378.276./ha/year. The farmers might be potential and comitmen in PUSK proggram were 74,60\%. There were correlation of the readness farmers with perseption farmers as supporting PUSK proggram $\alpha=5 \%$, so PUSK proggram PUSK can to buid.
\end{abstract}

Key Words : Domestication of silk, Farmer rice

\section{PENDAHULUAN}

Kabupaten OKU Timur merupakan daerah penghasil beras terbanyak di Propinsi Sumatra Selatan, dengan didukung saluran irigasi teknis dan bendung Perjaya yang mampu mengairi sebagaian besar areal persawahan yang ada di wilayah ini. Sejalan dengan adanya program Masterplan Percepatan dan Perluasan Pembangunan Ekonomi Indonesia (MP3EI) dalam Peraturan Presiden Republik Indonesia No. 32 Tahun 2011 yang digalakkan pemerintah sejak tahun 2011, Maka salah satu strategi pemerintah khususnya dalam menyehatkan kondisi sosial ekonomi masyarakat, diperlukan suatu upaya mendorong warga untuk memaksimalkan pemanfaatan potensi sumberdaya yang dimiliki daerah itu secara maksimal. Jika potensi daerah, khususnya potensi sosial ekonomi yang dimiliki petani ini dapat dimanfaatkan dengan baik, maka diharapkan setiap keluarga petani akan mampu menambah sumber pendapatannya sehingga mampu memenuhi kebutuhan hidup sehari-hari, tanpa harus ada yang yang mengalami kesulitan keuangan terutama saat musim paceklik tiba, karena bisa dipenuhi dengan cara melakukan usaha sampingan. Akan tetapi, realitasnya petani di daerah beririgasi ini kebanyakan masih mengalami kesulitan dalam meningkatkan kesejahteraan mereka (Sudarti, 2014).

Kondisi ini dikarenakan (1) Produksi di lahan garapan petani kian sempit, sehingga kurang menjamin kecukupan pendapatan petani, (2) Pada saat paceklik harga beras meningkat, namun ketika musim panen, terjadi penurunan harga, (3) Pendapatan petani padi semakin berkurang akibat kenaikan biaya produksi seperti harga pupuk mahal, biaya jasa pengolahan lahan juga meningkat dengan menggunakan sistem bayar ketika panen (yarnen), dan biaya iuran pengairan dari saluran irigasi meningkat. Salah satu strategi untuk meningkatkan keluarga petani itu tentunya adalah upaya mendorong keluarga petani untuk memaksimalkan pemanfaatan potensi sosial ekonomi yang dimiliki keluarga petani secara maksimal seperti luas lahan pekarangan, jumlah tenaga kerja, dan pendapatan. Adapun alternatif usaha yang memiliki prospek cukup cerah yakni budidaya sutera alam jenis Attacus atlas.

Sutera merupakan jenis komoditi bernilai tinggi, karena dalam proses produksi yang diihasilkan oleh ulat sutera memiliki nilai jual yang tinggi baik dari segi kualitas barang dan segi harga jual kain sutera. Budidaya sutera mudah dilakukan, mengingat investasinya relatif rendah, teknologinya sederhana, bersifat padat karya, sementara pakannya dapat ditanam di mana saja, seperti di pekarangan rumah, lahan kurang subur, lahan tidur atau lahan kritis. Seperti halnya di Kabupaten OKU Timur dilihat dari keadaan wilayah secara makro (Keadaan luas lahan pekarangan, banyaknya jenis pakan yang ada dan respon masyarakat) berpotensi untuk dijadikan sebagai tempat untuk pengembangan agribisnis sutara jenis Attacus atlas 
kerakyatan.Alasan yang menguatkan keyakinan itu sebagai berikut :

1. Attacus atlas adalah serangga pemakan \pm 90 macam species tumbuhan (Peigler dalam Solihin dan Fuah, 2010)

2. Tersedianya jenis tanaman pakan ulat sutera jenis Attacus atlas di lahan pekarangan rumah petani diantaranya, tanaman jambu mente, jarak pagar, nangka sirsat, kaca piring, dll.

3. STIPER Belitang sedang melakukan domestikasi ulat sutera alam jenis Attacus atlas yang nantinya akan menjadi penyedia telur ulat sutera untuk dibudidayakan oleh petani mitra binaan.

Program pemberdayaan petani dalam meningkatkan pendapatan pokok dan pendapatan tambahan keluarga melalui sosialisasi Program Usaha Sutera Kerakyatan (PUSK) merupakan salah satu solusi yang relevan. Produk sutera yang hendak diperkenalkan pada petani yang ada di Kabupaten OKU Timur adalah budidaya ulat sutera alam jenis Attacus atlas yang kini sedang dipersiapkan oleh STIPER Belitang dengan program domestikasi ulat sutera jenis Attacus atlas liar yang berasal dari kawasan alam yang ada lingkungan sekitar di Kabupaten OKU Timur agar bisa dibudidayakan di rumah petani di Kabupaten OKU Timur. Selain itu, Kecamatan Belitang memiliki kawasan lahan pertanian yang subur yang dialiri pengairan irigasi teknis. Kondisi ini mendukung dan memungkinkan dapat tumbuhnya tanaman inang Attacus atlas di lahan pekarangan milik petani di sepanjang aliran irigasi teknis yang ada di kecamatan Belitang. Tersedianya pengairan yang cukup yang diperoleh dari irigasi teknis memungkinkan tanaman inang dapat tetap bertahan hidup dan tumbuh walau pada musim kemarau panjang sekalipun. Oleh karena itu, perlu dilakukan suatu kajian mengenai potensi sosial ekonomi yang dimiliki oleh petani yang ada di daerah ini, sehingga PUSK ini dapat menjadi daya tarik para petani padi.

Berdasarkan latar belakang itu maka perlu diadakannya kajian mengenai potensi sosial ekonomi yang dimiliki keluarga petani, yang dapat mendukung rencana program pengembangan usaha sutera kerakyatan (PUSK) yang akan dilaksanakan di wilayah Belitang III Kabupaten OKU Timur. Adapun tujuan dari penelitian ini penelitian sebagai berikut:

1. Menghitung besarnya potensi lahan pekarangan, tingkat pencurahan kerja, pendapatan usahatani padi dan respon petani untuk bisa menerima rencana program PUSK.

2. Menganalisis hubungan antara kesiapan petani dengan respon petani untuk bisa menerima rencana program PUSK.

\section{METODOLOGI PENELITIAN}

Penelitian telah dilaksanakan di beberapa desa yang dilintasi saluran irigasi teknis di Kecamatan Belitang Kabupaten OKU Timur. penetapan ini dilakukan secara sengaja (purposive) dengan pertimbangan bahwa petani di sepanjang saluran irigasi memiliki potensi besar untuk mengelola dan membudidayakan sutera alam. Penelitian ini telah dilaksanakan pada Bulan April sampai Agustus 2015. Metode yang digunakan dalam penelitian ini adalah metode survei dengan teknik sampling. Data yang dikumpulkan adalah data primer dan sekunder. Pengumpulan data primer telah dilakukan pada bulan Juni 2015, dengan cara wawancara yang dilengkapi dengan kuisioner. Sedangkan, metode penarikan contoh pada penelitian ini menggunakan metode penarikan contoh acak berlapis tak berimbang seperti berikut :

Tabel 1. Persentase Petani Contoh berdasarkan Saluran Irigasi

\begin{tabular}{|c|c|c|c|c|}
\hline $\begin{array}{c}\text { BK } \\
\text { (Desa) }\end{array}$ & $\begin{array}{c}\text { Saluran } \\
\text { Irigasi }\end{array}$ & $\begin{array}{c}\text { Jumlah } \\
\text { Populasi } \\
(\mathrm{KK})\end{array}$ & $\begin{array}{c}\text { Petani } \\
\text { Conto } \\
\mathrm{h} \\
(\mathrm{KK}) \\
\end{array}$ & $\begin{array}{c}\text { Persentase } \\
(\%)\end{array}$ \\
\hline \multirow{3}{*}{ VI } & Primer & 20 & 7 & 35,00 \\
\hline & $\begin{array}{l}\text { Sekunde } \\
\mathrm{r}\end{array}$ & 45 & 7 & 15,56 \\
\hline & Tersier & 47 & 7 & 14,89 \\
\hline \multirow{3}{*}{ VII } & Primer & 15 & 7 & 46,67 \\
\hline & $\begin{array}{l}\text { Sekunde } \\
\mathrm{r}\end{array}$ & 38 & 7 & 18,42 \\
\hline & Tersier & 42 & 7 & 16,67 \\
\hline \multirow{4}{*}{ VIII } & Primer & 27 & 7 & 25,93 \\
\hline & $\begin{array}{l}\text { Sekunde } \\
\mathrm{r}\end{array}$ & 49 & 7 & 14,29 \\
\hline & Tersier & 60 & 7 & 11,67 \\
\hline & Jumlah & 343 & 63 & 18,37 \\
\hline
\end{tabular}

\section{A. Kerangka Pemikiran}

Menurut Peigler dalam Solihin dan Fuah (2010), larva Ataccus atlas dapat memakan lebih dari 90 genus dari 48 familia, 
dan 40 jenis tanaman inang yang dapat dijadikan sebagai pakan larva Ataccus atlas diantaranya sirsak, srikaya, kenanga, kenanga besar, belimbing, bambu, barberi, teh, kenari, kopi, kamper, kayu manis, kayu manis, jeruk/lemon, mangga, kunyit, dadap, lengkeng, kembang sepatu, ubi jalar, leci, apel, murbei, alpukat, lada, randu, mawar, cokelat, gambir, jarak pagar dan mahoni (Solihin dan Fuah, 2010).

Selain itu, Menurut Deddy dan Asnath (2010), dalam satu siklus satu ekor Attacus atlas dapat mengonsumsi 85-135 gram daun segar. Daun sirsak merupakan salah satu daun yang berpotensi sebagai pakan larva Attacus atlas. Sedangkan penelitian yang telah dilakukan oleh Muridin (2014), menyebutkan bahwa 1 batang pohon sirsak yang sudah berumur 2 tahun dengan luasan lahan pekarangan sekitar $14 \mathrm{~m}^{2}$ yang tumbuh di pekarangan milik masyarakat Belitang dapat memenuhi kebutuhan pakan untuk 70 ekor ulat sutera jenis Attacus atlas.

Menurut Adliantos (1994), kegiatan persuteraan alam ini dapat dilakukan oleh pria, wanita maupun anak-anak dan dapat dijadikan sebagai pekerjaan pokok atau sebagai pekerjaan sampingan keluarga petani. Hasil observasi di lapangan menunjukkan bahwa bagi keluarga tani yang memiliki pelaung waktu yang banyak adalah kaum perempuan. Jumlah HOK yang terpakai hanya ketika musim tanam padi (tandur), penyiangan, itupun bekerja dimulai pukul 07.00 hingga 13.00. dan sebagian HOK hanya terpakai saat musim panen tiba. Sedangkan bagi wanita pekebun sebagian besar HOK terpakai untuk membantu suami di sawah atau kebun di Kabupaten OKU Timur.

Attacus atlas adalah salah satu jenis ulat sutera liar yang memiliki potensi sebagai sumber pendapatan keluarga. Harga kokon sutera liar cukup tinggi, yaitu 300.000 500.000 per $\mathrm{kg}$, sedangkan kokon sutera murbai (Bombyx mori) berharga Rp 200.000 350.000 per $\mathrm{kg}$. Untuk $1 \mathrm{~kg}$ kokon sebanyak 2.750 - 3.000 biji kokon yang kosong.Jika sudah dijadikan benang, harganya dapat mencapai Rp 1.000.000 - Rp 1.250.000 per $\mathrm{kg}$, tergantung dari kehalusan benang. Berdasarkan studi literatur, maka tersusunlah kerangka berfikir berupa model pendekatan diagramatik, bagan alir Gambar 1 . (Terlampir)

\section{B. Hipotesis}

Berdasarkan penelitian terdahulu dan kerangka pemikiran diagramatis, maka hipotesis yang dapat disimpulkan "Diduga bahwa terdapat korelasi positif antara kesiapan petani dengan respon petani untuk bisa menerima rencana program PUSK"

\section{Alat Analisis}

Data yang diperoleh dari lapangan diolah secara tabulasi dan menghitung secara matematik serta mendeskripsikannya.

Tabel 2. Indikator Pengukuran Potensi Sosial Ekonomi

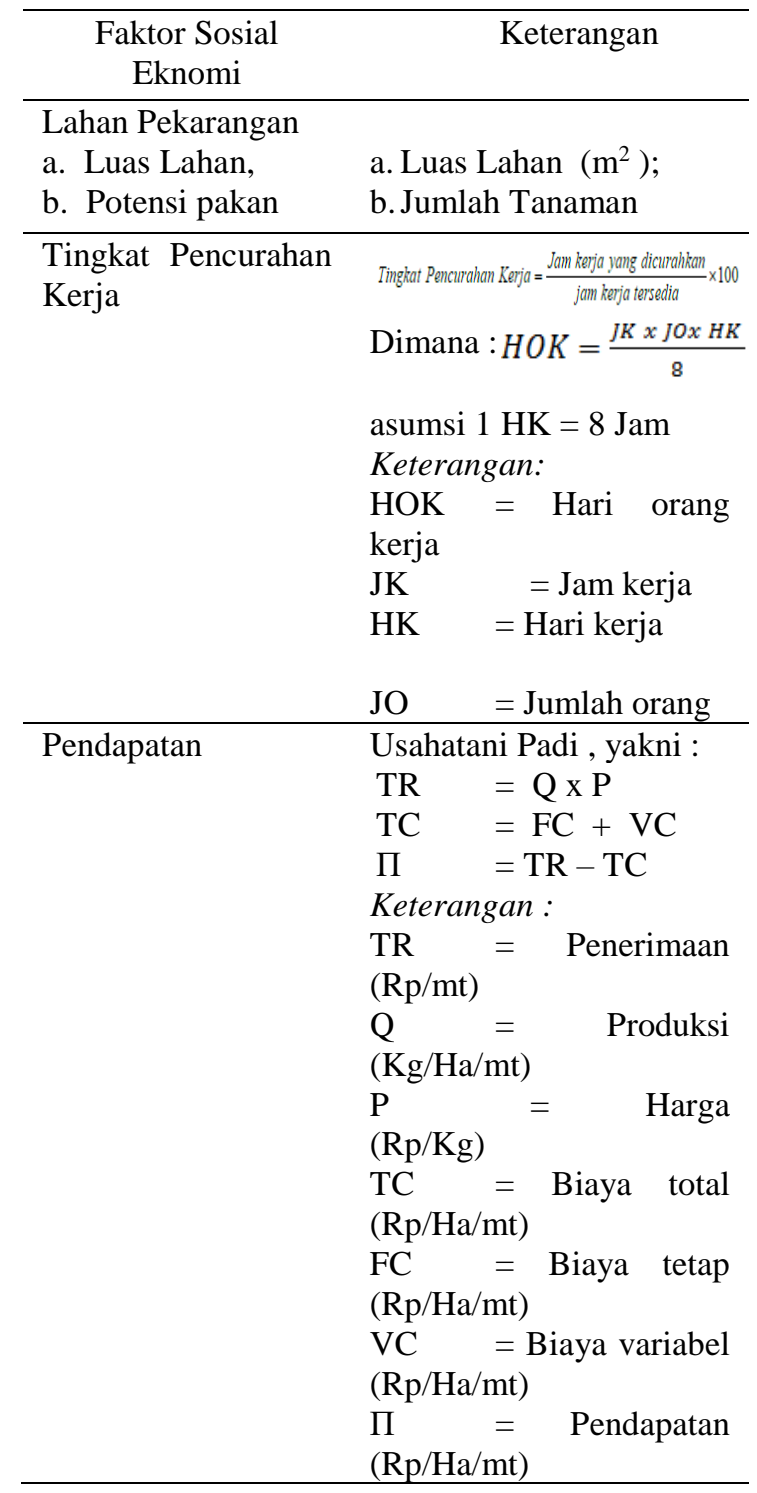

Setelah dihitung secara matematik, maka variabel lahan pekarangan, tenaga kerja keluarga, dan pendapatan dikelompokkan menjadi 2 kriteria yakni potensi siap dan tidak 
siap untuk bisa menerima rencana program PUSK.

Tabel 3. Kriteria Kesiapan Petani

\begin{tabular}{|c|c|c|c|}
\hline & $\begin{array}{c}\text { Faktor } \\
\text { Sosial } \\
\text { Ekonomi }\end{array}$ & Kriteria & Keterangan \\
\hline \multirow{4}{*}{$\begin{array}{c}\mathrm{X} \\
1\end{array}$} & \multirow{2}{*}{$\begin{array}{l}\text { Lahan } \\
\text { Pekarangan } \\
\left(\mathrm{m}^{2}\right)\end{array}$} & $\begin{array}{l}\text { Tidak } \\
\text { Siap }\end{array}$ & $\leq 200 \mathrm{~m}^{2}$ \\
\hline & & Siap & $>200 \mathrm{~m}^{2}$ \\
\hline & \multirow{2}{*}{$\begin{array}{l}\text { Potensi } \\
\text { Pakan }\end{array}$} & $\begin{array}{l}\text { Tidak } \\
\text { Siap }\end{array}$ & $\begin{array}{l}\quad \leq 3 \text { jenis } \\
\text { pakan }\end{array}$ \\
\hline & & Siap & $\begin{array}{l}>3 \text { jenis } \\
\text { pakan }\end{array}$ \\
\hline \multirow{2}{*}{$\begin{array}{l}\mathrm{X} \\
2\end{array}$} & \multirow{2}{*}{$\begin{array}{l}\text { Tingkat } \\
\text { Pencurahan } \\
\text { Waktu } \\
\text { Kerja (\%) }\end{array}$} & $\begin{array}{l}\text { Tidak } \\
\text { Siap } \\
\end{array}$ & $>50,00 \%$ \\
\hline & & Siap & $\leq 50,00 \%$ \\
\hline \multirow{3}{*}{$\begin{array}{l}X \\
3\end{array}$} & \multirow{3}{*}{$\begin{array}{l}\text { Pendapatan } \\
\text { Padi } \\
\text { (Rp/Tahun) }\end{array}$} & $\begin{array}{l}\text { Tidak } \\
\text { Siap }\end{array}$ & $\begin{array}{l}25 \mathrm{jt}-50 \\
\mathrm{jt} / \mathrm{tahun}\end{array}$ \\
\hline & & \multirow{2}{*}{ Siap } & $\begin{array}{l}10 \mathrm{jt}-25 \mathrm{jt} \\
/ \text { tahun }\end{array}$ \\
\hline & & & $\begin{array}{l}1 \mathrm{jt}-10 \mathrm{jt} / \\
\text { tahun }\end{array}$ \\
\hline
\end{tabular}

Sedangkan untuk mengukur respon petani untuk bisa menerima program PUSK menggunakan penskoran yang terdiri dari 10 pertanyaan, dengan kriteria bersedia dan tidak bersedia. Untuk melihat hubungan kesiapan dan respon petani untuk bisa menerima program PUSK menggunakan uji koefisien korelasi peringkat Spearman untuk dua arah dengan taraf nyata 0,05 maka didapatkan hipotesis yakni :

Ho = Kedua variabel bebas

Ha = Ada korelasi antara kedua variabel

Rumus matematis :

$\mathrm{r}_{\mathrm{s}=1-} \frac{6 \sum_{i=1}^{n} d i^{2}}{n\left(n^{2}-1\right)}$

; dimana :

2

$\sum d i^{2}=\sum_{i=1}\left\{R\left(x_{i}\right)-\left(y_{i}\right)\right\}^{2}$

Keterangan :

$\mathrm{r}_{\mathrm{s}}=$ statistik untuk koefisien korelasi Spearman

di $=$ selisih peringkat pengamatan $X$ dan $Y$

$\mathrm{R}$ = peringkat nilai data untuk $\mathrm{X}$ maupun $\mathrm{Y}$

Kaidah keputusan :
- $\quad$ Terima Ho, $r_{\mathrm{s}}$ hit $\leq \mathrm{r}_{\mathrm{s}} \alpha / 2$ (n), artinya kedua variabel bebas

- $\quad$ Tolak Ho, $r_{\mathrm{s}}$ hit $>\mathrm{r}_{\mathrm{s}} \alpha / 2$ (n), artinya terdapat hubungan (korelasi) yang positif atau negatif antara kesiapan petani dengan respon petani dalam rencana program PUSK.

\section{HASIL DAN PEMBAHASAN}

\section{A. Potensi Kesiapan Petani dan Respon Petani untuk Bisa Menerima Rencana Program PUSK.}

\section{A.1. Potensi Kesiapan Petani \\ a. Aspek Teknis (Lahan Pekarangan)}

Lahan pekarangan merupakan lahan di sekitar rumah yang berpotensi sebagai tempat menanam tanaman sebagai calon pakan ulat sutera Attacus atlas. Lahan pekarangan yang dimiliki petani contoh sangat beragam, tergantung besar kecilnya rumah dan cara penataan pekarangan itu. Berdasarkan hasil perhitungan diketahui bahwa petani yang memiliki luas pekarangan $\leq 200 \mathrm{~m}^{2}$ sebanyak 4 orang atau 6,35 persen. Sedangkan petani yang memiliki luas pekarangan $>200 \mathrm{~m}^{2}$ sebanyak 59 orang atau 93,65 persen dari total petani contoh sebanyak 63 orang. rata-rata luas lahan pekarangan di saluran primer $258 \mathrm{~m}^{2}$, saluran sekunder $242 \mathrm{~m}^{2}$, dan saluran tersier $258 \mathrm{~m}^{2}$. Menurut Arifin, (2013) luas pekarangan yang dimiliki petani ini tergolong dalam kriteria sedang. Hal ini didasarkan pada ukuran minimum lahan pekarangan yang dapat menyediakan tempat untuk ke 5 tanaman yang disebut dengan keragaman vertikal, serta tempat bagi 8 jenis kegunaan atau fungsi tanaman yang disebut sebagai keragaman horizontal.

Jika dilihat dari jenis pakan yang tersedia, maka tanaman kaca piring dan jarak pagar yang lebih banyak tersedia di lahan pekarangan petani. Lahan pekarangan ini dapat ditanami berbagai jenis tanaman. Hal ini dikarenakan ulat sutera jenis Attcus atlas dapat memakan 99 jenis tanaman. Sebaiknya tanaman yang dipilih adalah jenis tanaman yang tidak hanya berfungsi sebagai pakan, tetapi tanaman yang memiliki manfaat lainnya seperti kaca piring sebagai pagar hidup, dan bunganya dapat dijadikan bahan baku pembuatan minyak wangi. Adapun potensi 
kesiapan luas pekarangan dan jenis pakan dapat dilihat pada Tabel 4.

Tabel 4.Potensi Kesiapan Lahan Pekarangan

\begin{tabular}{|c|c|c|c|c|c|}
\hline \multirow{3}{*}{\multicolumn{2}{|c|}{$\begin{array}{c}\text { Potensi Lahan Pekarangan } \\
\text { di Saluran Primer }\end{array}$}} & \multicolumn{4}{|c|}{ Jenis Tanaman } \\
\hline & & \multicolumn{2}{|c|}{ Siap } & \multicolumn{2}{|c|}{ Tidak Siap } \\
\hline & & org & $\%$ & org & $\%$ \\
\hline \multirow{2}{*}{$\begin{array}{c}\text { Luas } \\
\text { Pekarangan }\end{array}$} & Siap & 17 & 89,47 & 2 & 100,00 \\
\hline & Tidak Siap & 2 & 10,53 & 0 & 0,00 \\
\hline \multicolumn{2}{|c|}{ Jumlah } & 19 & 100,00 & 2 & 100,00 \\
\hline \multirow{3}{*}{\multicolumn{2}{|c|}{$\begin{array}{l}\text { Potensi Lahan Pekarangan } \\
\text { di Saluran Sekunder }\end{array}$}} & \multicolumn{4}{|c|}{ Jenis Tanaman } \\
\hline & & \multicolumn{2}{|c|}{ Siap } & \multicolumn{2}{|c|}{ Tidak Siap } \\
\hline & & org & $\%$ & org & $\%$ \\
\hline \multirow{2}{*}{$\begin{array}{c}\text { Luas } \\
\text { Pekarangan }\end{array}$} & Siap & 11 & 100,00 & 10 & 100,00 \\
\hline & Tidak Siap & 0 & 0,00 & 0 & 0,00 \\
\hline \multicolumn{2}{|c|}{ Jumlah } & 11 & 100,00 & 10 & 100,00 \\
\hline \multirow{3}{*}{\multicolumn{2}{|c|}{$\begin{array}{l}\text { Potensi Lahan Pekarangan } \\
\text { di Saluran Tersier }\end{array}$}} & \multicolumn{4}{|c|}{ Jenis Tanaman } \\
\hline & & \multicolumn{2}{|c|}{ Siap } & \multicolumn{2}{|c|}{ Tidak Siap } \\
\hline & & org & $\%$ & org & $\%$ \\
\hline \multirow{2}{*}{$\begin{array}{c}\text { Luas } \\
\text { Pekarangan }\end{array}$} & Siap & 8 & 100,00 & 11 & 84,62 \\
\hline & Tidak Siap & 0 & 0,00 & 2 & 15,38 \\
\hline \multicolumn{2}{|c|}{ Jumlah } & 8 & 100,00 & 13 & 100,00 \\
\hline \multirow{3}{*}{\multicolumn{2}{|c|}{$\begin{array}{l}\text { Total Potensi Lahan } \\
\text { Pekarangan }\end{array}$}} & \multicolumn{4}{|c|}{ Jenis Tanaman } \\
\hline & & \multicolumn{2}{|c|}{ Siap } & \multicolumn{2}{|c|}{ Tidak Siap } \\
\hline & & org & $\%$ & org & $\%$ \\
\hline Luas & Siap & 36 & 94,74 & 23 & 92,00 \\
\hline Pekarangan & Tidak Siap & 2 & 5,26 & 2 & 8,00 \\
\hline \multicolumn{2}{|c|}{ Jumlah } & 38 & 100,00 & 25 & 100,00 \\
\hline
\end{tabular}

Pada Tabel 4. diketahui bahwa terdapat 4 potensi lahan pekarangan yang akan ditemukan di lahan pekarangan milik petani yakni (1) Potensi lahan pekarangan dan jenis pakan tergolong siap sebesar 94,74\% (2) Potensi lahan pekarangan siap, namun jenis pakan tidak siap sebesar 92,00\% (3) Potensi lahan pekarangan tidak siap, tetapi jenis pakan siap sebesar 5,26\% (4) Potensi lahan pekarangan dan jenis pakan tergolong tidak siap sebesar $8,00 \%$. Jika dilihat dari persentase potensi kesiapan lahan pekarangan tipe 1 dan 2, maka potensi lahan pekarangan ini memungkinkan petani untuk bisa menerima rencana program PUSK. Akan tetapi jika tipe 2 yang terjadi petani harus mau menanam jenis pakan di lahan pekarangannya untuk memenuhi pakan ulat sutera yang akan didomestikasi.

\section{b. Aspek Manajemen (Tenaga Kerja)}

Ketersediaan tenaga kerja dalam keluarga berasal dari jumlah keseluruhan anggota keluarga baik laki-laki maupun perempuan dan juga anak-anak. Tenaga kerja yang tersedia akan digunakan untuk melakukan usahatani padi sawah sebagai pendapatan pokok keluarga dan tenaga kerja yang lainnya akan digunakan sebagai kegiatan lain diantaranya, untuk kegiatan usaha sampingan, dan untuk rencana program PUSK. Adapun rata-rata jumlah tenaga kerja yang tersedia dalam keluarga petani dapat dilihat Pada Tabel 5.

Tabel 5. Potensi Kesiapan Tenaga Kerja

\begin{tabular}{|c|c|c|c|c|}
\hline \multirow{2}{*}{ Uraian } & \multicolumn{4}{|c|}{ Tenaga Kerja Tersedia (HOK/Tahun) } \\
\hline & JO & $\mathrm{JK}$ & HK & HOK \\
\hline Primer & 2,17 & 2.880 & 360 & 281.417 \\
\hline Sekunder & 2,00 & 2.880 & 360 & 259.817 \\
\hline Tersier & 2,29 & 2.880 & 360 & 296.229 \\
\hline Rata-Rata & 2,15 & 2.880 & 360 & 279.154 \\
\hline
\end{tabular}

Potensi tenaga kerja dari semua saluran adalah $279.154 \mathrm{jam} / \mathrm{tahun}$ dengan rata-rata jumlah orang $=2,15$. Sedangkan jam kerja yang dipakai adalah standar jam kerja yaitu 8 jam per hari dikalikan jumlah hari yang digunakan untuk bekerja selama satu tahun, yaitu 360 hari. Sehingga didapat sisa waktu kerja. Adapun rinciannya dapat dilihat pada Tabel 6.

Tabel 6. Potensi Tingkat Pencurahan Waktu Kerja

\begin{tabular}{|c|c|c|c|c|c|c|c|}
\hline \multirow{2}{*}{ Vraina } & \multirow{2}{*}{$\begin{array}{c}\text { Tenagga Kerja } \\
\text { Tersedia }\end{array}$} & \multicolumn{4}{|c|}{ Tenageg Kejja Tecurad } & \multirow{2}{*}{$\begin{array}{c}\text { Sisa Wadu } \\
\text { Kerja }\end{array}$} & \multirow{2}{*}{ 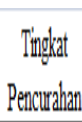 } \\
\hline & & UTPad & Non:Padi & Non:UI & Total & & \\
\hline Pimer & 281.417 & 82.49 & 35.577 & 2224 & 120.209 & 161.208 & 57,28 \\
\hline Selender & 259.817 & 86628 & 8.212 & 2224 & 97.063 & 162.754 & 02,64 \\
\hline Tersier & 296.229 & 101.354 & 9.362 & 2341 & 113.057 & 183.12 & 01,83 \\
\hline Rata-Rata & 279.154 & 90.130 & 179.119 & 2.663 & 110.110 & 169.45 & 60,56 \\
\hline
\end{tabular}

Berdasarkan rincian sisa jam kerja tidak terpakai pada saluran primer, sekunder, dan tersier diketahui bahwa rata-rata petani memiliki sisa waktu kerja $169.045 \mathrm{Jam} / \mathrm{Tahun}$ dengan tingkat pencurahan 60,56 persen. Petani di saluran primer memiliki waktu luang lebih sedikit dari petani yang berdomisili di sekitar saluran sekunder dan tersier. Hal ini dikarenakan petani yang berdomisili di sepanjang saluran primer memiliki alternatif usaha lain selain padi.

Berdasarkan ketersedian tenaga kerja dapat dikategorikan siap. Hasil perhitungan setelah dikalsifikan menunjukkan bahwa 59 orang atau 93,65 persen dari total petani contoh sebanyak 63 orang memiliki tingkat pencurahan waktu kerja $\leq 50,00 \%$, dan hanya sebesar 6,35 persen petani yang tidak siap. Secara teoritis, tiap anggota rumah tangga akan mencurahkan waktunya pada usaha domestikasi ulat sutera bila pendapatan yang dihasilkan dari usaha itu menarik baginya. 


\section{c. Aspek Ekonomi (Pendapatan)}

Pada Tabel 7 dapat dilihat bahwa ratarata pendapatan yang diperoleh petani di saluran primer dan saluran sekunder masing masing sebesar Rp.20.430.638/Ha/Tahun dan Rp.19.694.334/Ha/Tahun, sedangkan pendapatan usahatani padi saluran tersier yakni hanya sebesar Rp.18.026.452/Ha/Tahun.

Tabel 7. Pendapatan Usahatani Padi .

\begin{tabular}{|c|c|c|c|c|c|c|c|c|}
\hline \multirow{3}{*}{ Urialan } & \multicolumn{2}{|c|}{ Pimer } & \multicolumn{2}{|c|}{ Sekunder } & \multicolumn{2}{|c|}{ Tersier } & \multicolumn{2}{|c|}{ Ratarforda } \\
\hline & 0,66 & & 0,74 & & 0,76 & & 0,7 & \\
\hline & \multicolumn{8}{|c|}{ 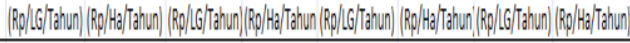 } \\
\hline Biaptetipo & 5.855 .125 & 8886337 & 6.778 .460 & 9.056498 & 5.2035 .548 & 6.8258 .818 & 5,932330 & 8.255 .228 \\
\hline Biay Variabel & 11166094 & 16.822796 & 11853.21 & 15930.78 & 16320.640 & 21.488797 & $13,113.615$ & $18.137,780$ \\
\hline Biaperodouki & $17022109^{\prime}$ & 25.6991 .133 & 18599.687' & 24987,227 & $21524.128^{\prime}$ & 28.244615 & $19.055,944$ & 263.3930 .08 \\
\hline Produki & 9.10 & 13733 & 9.934 & 13.351 & 10.857 & 14.242 & 9,964 & 13.781 \\
\hline Harge & 3.358 & $3.358^{\prime}$ & 3.347 & $3.497^{\prime}$ & 3.248 & $3.248^{\prime}$ & 3,318 & 3.318 \\
\hline Peneniman & 30.5598839 & 6119771. & 333.255 .209 & 4,680.56. & 35.266 .34 & $45.62101068^{\prime}$ & 33,023001 & $45,72.283$ \\
\hline Pendopatian & 13537,730 & $20,40,6038$ & 146535.522 & 19.6943 .34 & 13.7242166 & $180.066453^{\prime}$ & $13,977,006$ & 19.378 .276 \\
\hline
\end{tabular}

Berdasarkan Tabel 7 ini terlihat bahwa pendapatan petani yang berdomisili di sekitar saluran primer lebih besar daripada petani yang berdomisili disekitar saluran sekunder dan tersier. Hal ini dikarenakan jarak atau atau letak sawah sebagian besar petani yang berada di saluran sekunder dan tersier jauh dari saluran primer. Kondisi ini menyebabkan sawah yang di terletak di dekat saluran sekunder dan tersier mendapatkan pengairan yang kurang baik, sehingga dapat berpegaruh pada produksinya

Potensi kesiapan petani berdasarkan pendapatan usahatani padi tergolong siap. Rata-rata pendapatan usahatani tergolong rendah dan sedang dengan persentase sebesar 84,13 persen. Sedangkan pendapatan petani yang tinggi hanya sebesar 15,87 persen. Petani yang memiliki pendapatan tinggi kurang bersedia mengikuti program PUSk. Hal ini dikarenakan petani yang memiliki pendapatan tinggi lebih cenderung memilih memodalkan uangnya untuk berkebun seperti menanam tanaman karet, dan sawit.

Secara keseluruhan dapat disimpulkan bahwa potensi kesiapan petani meliputi aspek teknis (lahan pekarangan), aspek manajemen (tenaga kerja), dan aspek ekonomi (pendapatan usahatani padi) tergolong siap dengan nilai sebesar 79,39 persen. Hal ini dapat dilihat pada Tabel 8. Maka dapat disimpulkan jika dilihat dari potensi kesiapan petani rencana program PUSK ini akan mudah terjadi.

Tabel 8.Potensi Kesiapan Petani (Lahan Pekarangan, Tenaga Kerja, Pendapatan) di Kawasan Beririgasi.

\begin{tabular}{|c|c|c|c|c|c|c|c|c|}
\hline \multirow{2}{*}{ Uająan } & \multicolumn{2}{|c|}{ Primer } & \multicolumn{2}{|c|}{ Sekunder } & \multicolumn{2}{|c|}{ Tersier } & \multicolumn{2}{|c|}{ Rata-Rata } \\
\hline & Org & $\%$ & Org & $\%$ & Org & $\%$ & Org & $\%$ \\
\hline Siap & 16 & $70,19^{\prime}$ & 15 & $71,43^{\prime}$ & 19 & 90,48 & 50 & 79,37 \\
\hline Tiddak Siap & 5 & $2,81^{\prime}$ & 6 & $28,57^{\prime}$ & 2 & 9,52 & 13 & 20,63 \\
\hline Jumlath & 21 & 100,00 & 21 & 100,00 & 21 & 100,00 & 63 & 100,00 \\
\hline
\end{tabular}

Akan tetapi, potensi kesiapan petani harus juga didukung oleh respon petani dalam rencana program PUSK. Hal ini dikarenakan, petani yang memiliki potensi kesiapan petani yang tergolong siap, belum tentu memiliki respon yang baik untuk bisa menerima rencana program PUSK ini.

\section{A.2. Respon Petani tentang Rencana Program PUSK}

Berdasarkan hasil identifikasi mengenai respon petani tentang rencana program PUSK diketahui bahwa $88,89 \%$ dari total petani contoh sebanyak 63 orang menyatakan setuju untuk bisa maenerima rencana program PUSK. Sedangkan, hanya $11,11 \%$ petani yang memberikan respon kurang setuju. Petani yang memiliki respon setuju ini sebagian besar petani yang berdomisili di kawasan saluran sekunder dan tersier. Sedangkan petani yang berdomisili di sepanjang saluran primer, lebih memilih untuk berdagang seperti warung makanan, dan tampal ban. Keadaan seperti ini menunjukkan bahwa rencana program PUSK akan lebih mudah untuk terealisasikan. Hal ini dikarenakan dengan adanya program PUSK, petani mengharapkan pendapatan mereka akan meningkat dari sebelumnya.Adapun ringkasannya mengenai rata-rata respon petani dalam rencana program PUSK dapat dilihat pada Tabel 9.

Tabel 9. Respon Petani tentang Rencana Program PUSK.

\begin{tabular}{|c|c|c|c|c|c|c|c|c|}
\hline \multirow{2}{*}{ Uir } & \multicolumn{2}{|c|}{ Primer } & \multicolumn{2}{|c|}{ Selunder } & \multicolumn{2}{|c|}{ Tesier } & \multicolumn{2}{|c|}{ Pritar Patlo } \\
\hline & $\mathrm{Org}$ & y & Org & y & Org & y & org & y \\
\hline Settuy & 19 & 90,18 & 18 & 85,7 & 19 & 90,48 & 36 & 80,8 \\
\hline 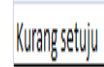 & 1 & $9,22^{\prime}$ & 3 & 14,2 & 2 & 9,52 & 7 & 111 \\
\hline Jumbh & 21 & 100000 & 21 & 100,0 & 4 & 100,0 & 63 & 100, \\
\hline
\end{tabular}


Berdasarkan hasil analisis mengenai respon petani ini didapat nilai korelasi untuk item pertanyaan 1 nilai kurang dari 0,312 , maka item itu tidak berkorelasi signifikan dengan skor total (dinyatakan tidak valid) sehingga untuk penelitian selanjunya harus diperbaiki. Sedangkan pada item-item lainnya nilainya lebih dari 0,312 dan dapat disimpulkan bahwa butir instrument respon petani ini valid. Selain itu, hasil analisis didapat nilai Alpha sebesar0,488. Sedangkan nilai $\mathrm{r}$ kritis (uji 2 sisi) pada signifikasi, didapat 0,312 . Karena nilainya lebih dari 0,312 maka dapat disimpulkan bahwa butir-butir instrument itu reliable.

\section{B. Hubungan antara Kesiapan Petani dengan Respon Petani untuk bisa Menerima rencana program PUSK.}

Berdasarkan potensi kesiapan petani dan respon petani. Maka dapat diketahui 4 tipe kesiapan petani. Adapun hasil pengelompokannya dapat dilihat pada Tabel 10.

Tabel 10. Tipe Kesiapan Petani yang berada di Kawasan Beririgasi

\begin{tabular}{cccccccccc} 
Tipe & Kode & \multicolumn{2}{l}{ Primer } & \multicolumn{2}{l}{ Sekunder } & \multicolumn{1}{l}{ Tersier } & \multicolumn{3}{l}{ Rata-Rata } \\
\hline TS-KS & A & 0 & $0,000^{\prime}$ & 2 & $9,52^{\prime}$ & 1 & 4,76 & 3 & 4,76 \\
SP-KS & B & 2 & $9,52^{\prime}$ & 1 & $4,76^{\prime}$ & 0 & 0,00 & 3 & 4,76 \\
TS-SU & C & 5 & $23,81^{\prime}$ & 4 & $19,05^{\prime}$ & 1 & 4,76 & 10 & 15,87 \\
SPPSU & D & 14 & $66,67^{\prime}$ & 14 & $66,67^{\prime}$ & 19 & 90,48 & 47 & 74,60 \\
\hline \multicolumn{2}{c}{ Jumlah } & 21 & 100,00 & 21 & 100,00 & 21 & 100,00 & 63 & 100,00 \\
\hline
\end{tabular}

Keterangan :

$\mathrm{A}=$ potensi SDA \& SDM tidak siap; respon petani kurang setuju (TS-KS )

$\mathrm{B}=$ potensi SDA \& SDM siap ; respon petani kurang setuju (SP-KS)

$\mathrm{C}=$ potensi SDA \& SDM tidak siap ; respon petani setuju (TS-SU)

$\mathrm{D}=$ potensi SDA \& SDM Siap ; respon petani sejutu (SP-SU)

Berdasarkan jumlah petani contoh sebanyak 63 orang yang diwawancarai terdapat $74,60 \%$ (kelompok D) dari petani yang tampaknya akan menjadi calon potensial untuk bisa menerima rencana program PUSK. Berdasarkan kondisi ini, program PUSK bukan salah satu alternatif yang suram untuk mendukung mata pencaharian petani padi. Adapun hubungan potensi kesiapan petani dengan respon petani untuk bisa menerima rencana program PUSK ini, maka dilakukan uji rank Spearman. Secara rinci, hasil uji rank
Spearman pada masing-masing saluran dapat dilihat pada Tabel 10 :

Tabel 10. Hasil uji rank Spearman

\begin{tabular}{|c|c|c|c|c|c|c|}
\hline \multirow{2}{*}{$\mathrm{N}=21$} & \multicolumn{2}{|c|}{ Primer } & \multicolumn{2}{|c|}{ Sekunder } & \multicolumn{2}{|c|}{ Tersier } \\
\hline & Corr.Coeff & Sig. & Corr.Coeff & Sig. & Corr.Coeff & Sig. \\
\hline Lahan Pekarangan & $.0,484$ & 0,026 & $\cdot 0,167$ & 0,470 & $\cdot 0,155$ & 0,503 \\
\hline Waktu Luang & $-0,082$ & 0,725 & 0,660 & 0,001 & $\cdot 0,496$ & 0,022 \\
\hline Pendapatan & 0,009 & 0,968 & $\cdot 0,496$ & 0,022 & $\cdot 0,731$ & 0,000 \\
\hline
\end{tabular}

Jika dilihat dari variabel lahan pekarangan maka hanya petani yang berdomisili di sekitar saluran primer yang menunjukkan bahwa terdapat hubungan yang negatif antara kesiapan petani (var.lahan pekarangan) dengan respon petani untuk bisa menerima program PUSK dengan rs-hitung sebesar $-0,484$ dan $\alpha=5 \%$. Jika dilihat dari variabel tenaga kerja maka diketahui hanya petani yang berdomisili di sekitar saluran sekunder dan tersier yang memiliki hubungan signifikan. Adapun nilai $\mathrm{r}_{\mathrm{s} \text {-hitung }}$ sebesar 0,660 dan $\alpha=1 \%$ (sekunder), dan $r_{\text {s-hitung }}$ sebesar 0,280 dan $\alpha=5 \%$. (tersier). Sedangkan jika dilihat dari variabel pendapatan diketahui bahwa $r_{\text {s-hitung }}$ sebesar $-0,731$ dan $\alpha=1 \%$ yang menunjukkan bahwa hanya petani yang berdomisili di sekitar saluran tersier yang memiliki hubungan negatif signifikan antara kesiapan petani (var.pendapatan) dengan respon petani untuk bisa menerima program PUSK.

\section{IV.KESIMPULAN DAN SARAN}

\section{A. Kesimpulan}

Berdasarkan hasil penelitian yang dilakukan dan dapat diambil kesimpulan :

1. Petani yang memiliki luas lahan pekarangan (Aspek Teknis) $>200 \mathrm{~m}^{2}$ ada sebanyak 93,65 persen, dan memiliki sisa waktu kerja (Aspek Manajemen) 169.045 HOK/Tahun dengan tingkat pencurahan wartu kerja rata-rata 62,64 persen. Sebagian waktu kerja ini tercurah untuk usahatani padi dengan menghasilkan pendapatan (Aspek Ekonomi) sebesar Rp.19.378.276/Ha/Tahun. Berdasarkan ketiga aspek ini, maka petani siap untuk bisa menerima rencana program PUSK.

2. Jika dilihat dari hubungan kesiapan petani dengan dan respon petani untuk bisa menerima program PUSK, maka ada 4 tipe hubungan yang akan terjadi, dan 
terlihat dari 4 hubungan itu ada sebesar 74,60 persen tampaknya akan menjadi calon potensial untuk bisa menerima rencana program PUSK Akan tetapi, hanya variabel kesiapan petani (waktu luang) petani yang berdomisili di sekitar saluran sekunder yang memiliki korelasi positif antara kesiapan petani dengan respon petani untuk bisa menerima rencana program PUSK dengan nilai $r_{\mathrm{s}-}$ hitung sebesar 0,660 dan $\alpha=1 \%$.

\section{B. Saran}

1. Bagi petani, petani yang memliki lahan lebih besar dari $200 \mathrm{~m}^{2}$ dan belum dikelola intensif, sebaiknya menanam tanaman berpotensi sebagai pakan seperti jarak, sirsak, mahoni, kaca piring. Sedangkan untuk, petani yang sudah ada tanaman potensial harus dirawat dengan baik karena tanaman itu memiliki nilai bila petani bersedia mengikuti program PUSK

2. Bagi STIPER BELITANG yang menjadi pusat kajian, agar secepat mungkin menghitung kebutuhan tanaman potensial sehingga dapat merekomendasikan kepada pemda terumatama Dinas Hutbun, untuk memberikan jenis tanaman yang dibutuhkan.

3. Bagi peneliti selanjutnya, agar lebih intens menggali peluang dengan lahan pekarangan dikarenakan degradasi lahan akan terus terjadi seiring dengan pertumbuhan penduduk, sehingga upaya mempertahankan pendapatan yang layak harus diperjuangkan

\section{DAFTAR PUSTAKA}

Ghonimah, Za. 2014. Rasionalitas Sosial Ekonomi Pengolahan Limbah Kokon Ulat Sutera (Attacus Atlas). Magister Agribisnis Fakultas Pertanian Universitas Sriwijaya. Inderalaya. Tesis. Tidak Dipublikasikan.

Muridin. 2014. Analisis Potensi Mikro Usaha dan Makro wilayah Pengembangan Agribisnis Sutera (Attacus Atlas) Kerakyatan di Kabupaten OKU Timur. Magister Agribisnis Fakultas Pertanian Universitas Sriwijaya.
Inderalaya. Tesis. Tidak Dipublikasikan

Sudarti, 2014 Potensi Sosial Ekonomi Petani Padi Dan Faktor Penentu Strategi Penyuluhan Untuk Pengembangan Usaha Sutera Kerakyatan (PUSK) di Kawasan Beririgasi Belitang III OKU Timur. Magister Agribisnis Fakultas Pertanian Universitas Sriwijaya. Inderalaya. Tesis. Tidak Dipublikasikan

Singarimbun dan Effendi. 1989. Metode Penelitian Survei Edisi Revisi. LP3ES. Jakarta.

Solihin, dan Fuah. 2010. Budidaya Ulat Sutera Alam. Penebar Swadaya : Jakarta

Sumodiningrat, G. 2000. Pembangunan

Ekonomi Melalui Pengembangan

Pertanian : Pengantar Menteri Pertanian.

PT. Bina Rena Pariwara : Jakarta.

Usman dan Akbar. 1995. Pengantar Statistika. Bumi Aksara. Jakarta.

Vauka, S. 2012. Pertimbangan sosio-entropic terhadap rencana pembentukan agribisnis persutraan kerakyatan di kecamatan Belitang, Kabupaten OKU Timur. Magister Agribisnis Fakultas Pertanian Universitas Sriwijaya. Inderalaya. Tesis. Tidak Dipublikasikan. 


\section{Lampiran.}

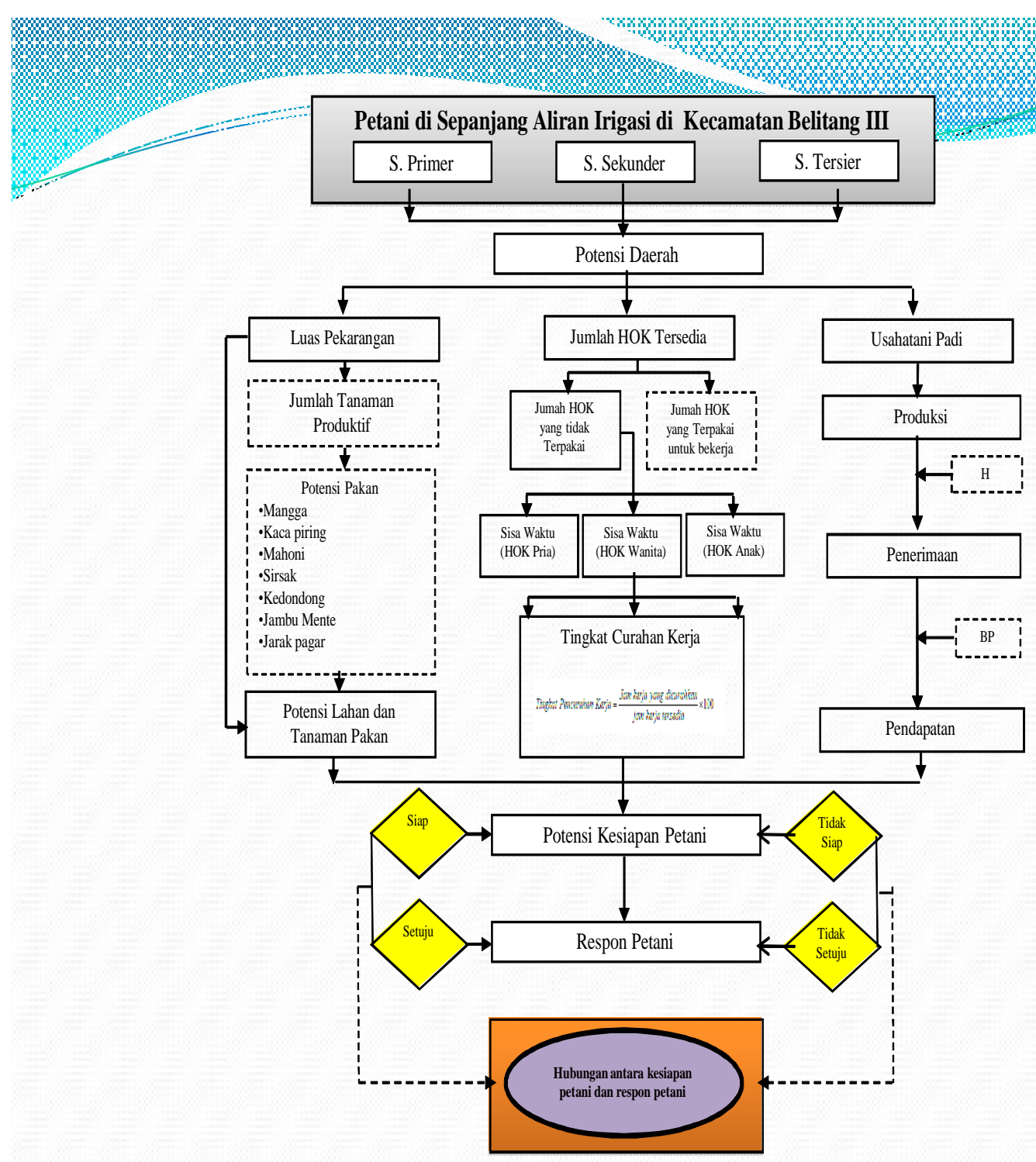

